\title{
Local Superior Products in Fishery Sector in Banggai Regency Indonesia
}

\author{
Nurhidayah Layoo ${ }^{1}$, Wahyudin Rahman ${ }^{2}$, Sutrisno K. Djawa ${ }^{3}$, Nurmawati Mambuhu ${ }^{4}$, Sri Sukari Agustina ${ }^{5}$, \\ Tasruddin $^{6}$, Lady Diana Khartiono ${ }^{7}$, Erwin Wuniarto ${ }^{8}$, Lutfi Samaduri $^{9}$, Nuning Kurniasih $^{10}$ \\ ${ }^{1,2,3,4}$ Management Study Program, Economy and Business of Faculty, Muhammadiyah Luwuk University, Luwuk, , Indonesia \\ ${ }_{5,6,7,8}$ Aquaculture Study Program, Fishery of Faculty, Muhammadiyah Luwuk University, Luwuk, Indonesia \\ ${ }^{9}$ Agribusiness Study Program, Agriculture of Faculty, Muhammadiyah University, Luwuk, Indonesia \\ ${ }^{10}$ Faculty of Communication Sciences, Library and Information Science Program, Universitas Padjadjaran, Bandung, Indonesia \\ *Corresponding author E-mail: wahyu@unismuhluwuk.ac.id
}

\begin{abstract}
The fisheries sector is one of the prima donna of Banggai Regency because the maritime and fisheries sector development is mentioned in the vision statement of the Banggai Regency Government.

The purpose of this research was to determine superior local products in the sub-sector of the processing industry of Banggai Regency Indonesia by using Analytic Hierarchy Process (AHP) approach. This research aims to determine the superior local product in the fishery sector of Banggai Regency Indonesia with the Analytic Hierarchy Process (AHP) approach and supported by Expert Choice 11 software. The research was conducted based on several criteria such as production facility availability, market potential, human resource support, uniqueness, and economic contribution. The data were taken by purposive sampling method by considering the capacity and ability of respondents consisted of 15 SMEs stakeholders in fishery sector, 12 heads of division in Fisheries and Marine Affairs Department, and 7 academics in Faculty of Fishery, and 5 Faculty of Economics. The data were collected through Focus Group Discussion (FGD) and indepth interview. The result shows that the priority of superior local products of Banggai Regency can be developed by the local government namely wild fisheries products (pelagic fish species). In addition, the emphasis in aspects of human resources and means of production facilities.
\end{abstract}

Keywords: Local Superior Product, Fishery Sector, Analytic Hierarchy Process

\section{Introduction}

The fisheries sector is one of the prima donna of Banggai Regency because the maritime and fisheries sector development is mentioned in the vision statement of the Banggai Regency Government. This sector continues to be encouraged by its development, until 2017 for the first time successfully exporting marine fishery products to several countries. The vision of the regional government is based on the magnitude of fishery potential in this region, especially capture fisheries and its contribution to the Gross Regional Domestic Product (PDRB), the Fisheries and Maritime Service of Banggai Regency reports that in the 1st and 2nd quarter of 2017, fisheries production in the capture fisheries sub-sector is $7,092,8$ tons with a production value of Rp. 108,878,100,000. According to BPS Banggai Regency, in 2016 the agriculture and fisheries sector contributed $23.98 \%$ to the total GRDP [1] [2] [3]. Based on the facts above, and so that the government can focus on development efforts, the products produced by businesses in the fisheries sector, where all of them are produced by small and medium micro enterprises, need to be identified to be selected as the superior regional products. Identification of regional superior products according to several previous studies [4] [5] [6] [7] used the Analytic Hierarchy Process (AHP) method, so that in this study was chosen as method for identifying superior products in the Banggai Regency in the fisheries sector. With this method, the government can establish a program that will focus more to devel- op LSP in order to create more employment opportunities, improve the society living standards, lower the poverty rate, and encourage the economic growth. In addition, Chuzaimah and Mabruroh [8] state that the optimization of LSP aims to increase employment opportunities, regional economic growth, OwnSource Revenue, as well as regional per capita income, and ultimately cut the poverty. To achieve so, the findings from the research are required to determine the LSP of Banggai Regency, set the priority scale from fishery sectors based on the production facilities, market potential, human resource support, uniqueness, and economic contribution.

\section{Method}

This research unit is all the stakeholders related to the LSP development in Fishery Sector in Banggai Regency Indonesia, namely local governments, entrepreneurs and academics. The research used purposive sampling by selecting 15 SMEs subjects. The expert group consisted of 3 heads of division in Industry and Trade Department, 3 heads of division in Cooperatives and SMEs, 3 heads of division in Fisheries and Marine Affairs Department, 5 academics from the Faculty of Fisheries, and 5 academics from Faculty of Economic.

The secondary data included legislation, research results, GRDP data, Number of fishery households data, data on fishery production, retrieved from the Central Bureau of Statistics and Fisheries and Marine Affairs Department. The primary data was collected 
from the research sample. The researchers carried out the data collection by conducting an in-depth interview with small business owners and FGD on the expert group.

The data analysis methods used were AHP method was used to set the priority scale of Banggai Regency LSP from fishery sectors, using five criteria. According to Saaty [9], the number of criteria or elements in a hierarchical model should be 5 to 9 so that they can be compared significantly to elements that are a level above them. The five criteria are Production facilities, market potential, Human Resource (HR) support, uniqueness, and economic contribution. It was supported by Expert Choice software.

\section{Result and Discussion}

The superior products of the selected area is the product that comes from the fishery sub-sector such as the aquaculture and fish farming. Since many households are involved in the said subsector and in almost all regencies, the number continued to increase in 2016.The dominant species of fish found in the marine waters of Banggai Regency are pelagic fish species that lives in sea level such as skipjack tuna (deho), redtailscad (malalugis) and long jawed mackerel (kadompe) are largely found in the sea of Banggai Regency. In addition, milkfish is largely cultivated by the society in fish farming. Banggai Regency has a total pond area of 81 ha, but all of them are still utilizing traditional fish farming techniques. Nile tilapia, catfish and carp are mainly cultivated in fish ponds. The total pond area is $9,450 \mathrm{~m} 2$, with the fish production per cycle is in the range of 148-248 fish (BPS Banggai Regency, 2017).

Table 1: Type of Fishery Product and Total Households Involvedin20152016

\begin{tabular}{|c|c|c|c|}
\hline No & $\begin{array}{c}\text { Type of Fishery } \\
\text { Product }\end{array}$ & $\begin{array}{c}\text { Total Households } \\
\mathbf{2 0 1 5}\end{array}$ & $\begin{array}{c}\text { Total Households } \\
\mathbf{2 0 1 6}\end{array}$ \\
\hline 1 & Wild Fishery & 3.224 & 3.376 \\
2 & Sea WaterPond Aqua- & 64 & 161 \\
3 & culture & 1.154 & 1750 \\
& Freshwater Pond & & \\
& Aquaculture & & \\
\hline
\end{tabular}

Source: [1] [2] [3]

By using AHP approach that divides the hierarchy structure into objective, criteria, and alternative, the following aspects are set:

Objective: Determine the LSP of Banggai Regency in Fishery Sector

Criteria : The availability of production facilities, market potential, HR support, uniqueness, and economic contribution

Alternative : There are three superior products (see figure 1)

The growing number of human resources should be balanced with the quality in an effort to improve the overall performance of the sector. The fisherman ability in accessing information of forecasting map of fishing area on Sulawesi Island published by Ministry of Marine Affairs and Fisheries through website http://kkp.go.id must be improved. By accessing this website, the fishermen are able to find the fish migration patterns that will help increasing the effectiveness and efficiency of fishing. In addition, improving the skills of fishermen in processing fishes into other various types of products is essential to avoid decrease in selling price when the amount of fish caught dramatically increases. Another solution proposed is to involve fishermen in agricultural extension programs as stated in the Regulation Number 7 of 2016 on Protection and Empowerment of Fishermen, Fish Farmers and Salt Farmers.

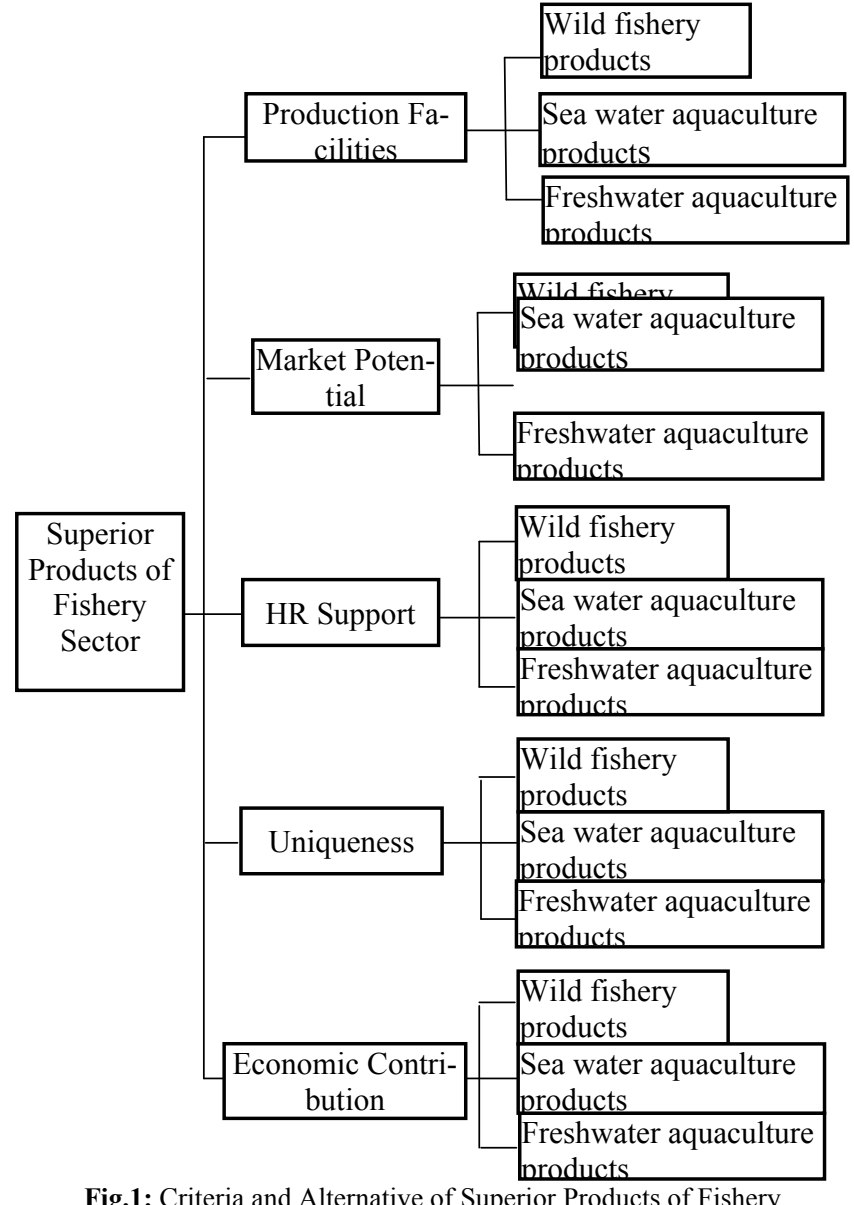

Fig.1: Criteria and Alternative of Superior Products of Fishery

\begin{tabular}{|lc|}
\hline \multicolumn{2}{l|}{ Priorities with respect to: } \\
Objective: SUPERIOR PRODUCTS OF BANGGAI \\
REGENCY \\
HUMAN RESOURCES & .361 \\
PRODUCTION FACILITIES & .257 \\
ECONOMIC CONTRIBUTION & .211 \\
MARKET POTENTIAL & .109 \\
UNIQUENESS & .062 \\
Inconsistency $=0.05$ with 0 missing judgments & \\
\hline \multicolumn{2}{|c}{ Fig.2: Criteria Weight Sequence } \\
\hline
\end{tabular}

Improve the production facilities, the fishing equipment used by traditional fishermen largely consist of 1994 units of handline fishing, 632 units of gill net, 627 units of gill net, 229 units of longline, 46 units of pajala and 40 units of bubu (fish trap) and sero, beach seine and purse seine 28 units each, 26 units of fishing rod, and a 19units of fishing float. While the fishing vesselsare still dominated by 2,592 units of small outboard motors. The type of motor boat that is widely used is a ship with a weight of 5 GT (Gross Tonnage). Therefore, it is crucial to improve the production facilities, including fishing vessels with a maximum size of $10 \mathrm{GT}$ as issued in the Regulation of the Minister of Maritime Affairs and Fisheries No. 71/PERMEN-KP/2016 that focuses on the regulations of fish farming, fish storage facility, and fish auction place (TPI). Providing and optimizing the function of TPI aims to accommodate the bargaining power of fishermen in determining selling price. So far, TPI only function as or fish landing or boat mooring. Fishery Products Market Potential Utilization, As issued by Law Number 7 of 2016, it is essential to actively 
encourage the investment in the industry of canned fish made of raw Pelagic dish caught by local fishermen in addition to the marketing cooperation with major retail companies for processed fish products from Banggai Regency.

Priorities with respect to:
Goal: SUPERIOR PRODUCTS OF BANGGAI REGEN-
CY IN FISHERY SECTOR
Wild fishery products
$\begin{aligned} & \text { Sea water aquaculture products } \\
& \text { Freshwater aquaculture products }\end{aligned}$
\begin{tabular}{l} 
Inconsistency $=0.00$ with 0 missing judgments \\
\hline
\end{tabular}

Fig. 3: LSP of fishery sector based on the Availability of Production Facilities

\begin{tabular}{|lc|}
\hline \multicolumn{2}{|l|}{ Priorities with respect to: } \\
Goal: SUPERIOR PRODUCTS OF BANGGAI REGEN- \\
CY IN FISHERY SECTOR \\
Wild fishery products & .487 \\
Sea water aquaculture products & .435 \\
Freshwater aquaculture products & .078 \\
Inconsistency $=0.01$ with 0 missing iudgments & \\
\hline
\end{tabular}

Fig. 4: LSP of fishery sector Based on Potential Market Criteria

Priorities with respect to:
Goal: SUPERIOR PRODUCTS OF BANGGAI REGEN-
CY IN FISHERY SECTOR
Wild fishery products
$\begin{aligned} & \text { Freshwater aquaculture products } \\
& \text { Sea water aquaculture products }\end{aligned}$
\begin{tabular}{l} 
Inconsistency $=0.06$ with 0 missing iudgments \\
\hline
\end{tabular}

Fig. 5: LSP of fishery sector Based on HR Support Criteria

\begin{tabular}{|l|}
\hline \multicolumn{2}{l}{ Priorities with respect to: } \\
Goal: SUPERIOR PRODUCTS OF BANGGAI REGEN- \\
CY IN FISHERY SECTOR \\
Wild fishery products \\
$\begin{array}{l}\text { Freshwater aquaculture products } \\
\text { Sea water aquaculture products }\end{array}$ \\
\begin{tabular}{l} 
Inconsistency $=0.00$ with 0 missing iudgments \\
\hline
\end{tabular} \\
\hline
\end{tabular}

Fig. 6: Local Superior Productsof fishery sector Based on Uniqueness Criteria

\begin{tabular}{|l|}
\hline Priorities with respect to: \\
Goal: SUPERIOR PRODUCTS OF BANGGAI RE- \\
GENCY IN FISHERY SECTOR \\
Wild fishery products \\
$\begin{array}{l}\text { Sea water aquaculture products } \\
\text { Freshwater aquaculture products }\end{array}$ \\
\begin{tabular}{l} 
Inconsistency $=0.00$ with 0 missing iudgments \\
\hline
\end{tabular}
\end{tabular}

Fig. 7: Local Superior Products of fishery sector Based on Economic Contribution Criteria
The wild fishery products ranked first in the LSP of Banggai District as seen from the human resource aspect (see Figure 2). Due to the number of households involved in the industry, it shows better performance compared with other sub-sectors such as sea water aquaculture and freshwater aquaculture. According to the data recorded by BPS in 2017, the number of households involved in wild fishery reached 3,376 households. Therefore, thewild fishery products need to be prioritized due to its large market potential, the sufficient amount of products, as well as the high domestic and global market demand.

The growing trend of fish consumption increases the market potential of fishery products. According to BPS data, the fish consumption expenditure of Banggai Regency was IDR $47,721 /$ capita/month in 2016 or $12.63 \%$ of the total food consumption expenditure, while the average consumption of Indonesian population in 2016 was $43.88 \mathrm{~kg} / \mathrm{capita} /$ year. It is considerably higher compared with 2015 in which the expenditure only reached $41.11 \mathrm{~kg} / \mathrm{capita} /$ year and in 2014 by $38.14 \mathrm{~kg} / \mathrm{capita} /$ year. The global market also opens a great opportunity for fish product export. Therefore, it is possible to expand the market not only by exporting fresh fish overseas but also the processed products as well.

A processed fish product that has a large export market potential but has not been optimized so far is canned fish. According to Kusdiana dan Gunardi, [10], Indonesian canned fish exports have successfully penetrated the market of United States, Japan and European Union. Considering that most of Indonesian canned fish market is dominated by export market, the government of Banggai Regency must actively encourage and utilize the domestic fishery industry.

The development of sea water aquaculture and freshwater aquaculture is expected to reduce the poverty rate of the area. The fact is that $35.49 \%$ of Lamala population subdistrict, a subdistrict wellknown for being a producer of seawater and freshwater fishes, still live below the poverty line. In Luwuk Timur subdistrict, $26.19 \%$ of the population live below the poverty line too..

The local government should optimize the potential of wild fishery products by small scale fishermen as the number is dominant. In addition, the small scale fishermen also need the support from local government in terms of protection and empowerment. According to the Law Number 7 of 2016 on Protection and Empowerment of Fishermen, fish farmers and salt farmers: small scale fishermen are individuals who earn their livelihood by capturing fish with or without using fishing vessels that are 10 tons gross at maximum. Regarding this matter, the government has also issued a policy that protects the rights of the fishermen in the Regulation of the Minister of Marine Affairs and Fisheries of the Republic of Indonesia No. 71/PERMEN-KP/2016 on Fishing Lines and Fishing Equipment Placement in Fisheries Management Area of the Republic of Indonesia [11] [12] [11] [13].

\section{Conclusion}

The fishery products come from the wild fishery, seawater aquaculture, and freshwater aquaculture. Priority of superior local products of Banggai Regency can be developed by the local government namely wild fisheries products (pelagic fish species). In addition, the emphasis in aspects of human resources and means of production facilities

\section{Acknowledgment}

This paper is part of the results of the study entitled Determining Local Superior Products Using Analytic Hierarchy Process Approach: A case study in Banggai Regency Indonesia. That the superior products of Banggai Regency are coconut products, Pelagic fish, processed food and beverage products 


\section{References}

[1] BPS Kabupaten Banggai, "BPS KabupatenProduk Domestik Regional Bruto Kabupaten Banggai Menurut Lapangan Usaha 20122016," BPS Kabupaten Banggai, Banggai, 2017.

[2] BPS Kabupaten Banggai, "Banggai dalam angka," BPS Kabupaten Banggai, Banggai, 2017.

[3] BPS Kabupaten Banggai, "Indikator ekonomi Kabupaten Banggai," BPS Kabupaten Banggai, Banggai, 2017.

[4] e. Rahab, "Local Economic Development Strategi Base on Local Industrial Core Competence," International Journal of Business and Management, vol. 8, no. 16, pp. 41-47, 2013.

[5] Kusdiana and Gunardi, "Pengembangan Produk Unggulan UMKM Kabupaten Sukabumi," Trikonomika Vol 13 No 2 Desember, pp. 153-171, 2014.

[6] E. Darmanto, N. Latifah and N. Susanti, "PenerapanMetode AHP (Analytic Hierarchy Process) untuk Menentukan Kualitas Gula Tumbu," Jurnal Simetris Vol 5 No 1, pp. 75-82, 2014.

[7] N. Sandriana, A. Hakim and C. Saleh, "Strategi Pengembangan Produk Unggulan Daerah Berbasis Klaster di Kota Malang," Jurnal Reformasi vol 5 nomor 1,pp. 89-100, 2015.

[8] Chuzaimah and Mabruroh, "Chuzaimah dan Mabruroh, 2008. Identifikasi Produk Unggulan Berbasis Ekonomi Lokal untuk Meningkatkan PAD di Era Otonomi Daerah," in Seminar Nasional Aplikasi Sains dan Teknologi 2008, IST AKPRIND, 2008.

[9] T. Saaty, "Decision Making with The Analytic Hier-archy Process," Int. J. Services Sciences, Vol. 1, No. 1, 2008.

[10] Kusdiana and Gunardi, "Pengembangan produk unggulan UMKM Kabupaten Sukabumi," Trikonomika Vol 13 No , pp. 153-171, 2014.

[11] Presiden RI, "Instruksi Presiden nomor 6 tahun 2007 tentang percepatan sektor riil dan pembangunan usaha mikro kecil dan menengah," Sekretariat Negara, Jakarta, 2007.

[12] Menteri Dalam Negeri RI, "Peraturan Menteri Dalam Negeri nomor 9 tahun 2014 tentang pedoman pengembangan produk unggulan daerah," Depdagri RI, Jakarta, 2014.

[13] Menteri Kelautan dan Perikanan Republik Indonesia , "Peraturan Menteri Kelautan dan Perikanan Republik Indonesia Nomor 71/PERMEN-KP/2016 tentang Jalur Penangkapan Ikan dan Penempatan Alat PenangkapanIkan di Wilayah PengelolaanPerikanan Negara Republik Indonesia.," Kementerian Kelautan dan Perikanan Republik Indonesia, Jakarta, 2016. 